\title{
All things bright: copper grave goods and diet at the Neolithic site of Osłonki, Poland
}

Chelsea Budd ${ }^{1, *}$, Peter Bogucki ${ }^{2}$, Malcolm Lillie ${ }^{1}$, Ryszard Grygiel ${ }^{3}$, Wiesław Lorkiewicz ${ }^{4} \&$ Rick Schulting 5

${ }^{1}$ Department of Historical, Philosophical and Religious Studies, Umeå University, Sweden

${ }^{2}$ School of Engineering and Applied Science, Princeton University, USA

${ }^{3}$ Museum of Archaeology and Ethnography, Łódź, Poland

${ }^{4}$ Department of Anthropology, Łódź University, Poland

${ }^{5}$ School of Archaeology, University of Oxford, UK

*Author for correspondence ( : chelsea.budd@umu.se)

Received: Revised: Accepted:

Understanding socioeconomic inequality is fundamental for studies of societal development in European prehistory. This article presents dietary $\left(\delta^{13} C\right.$ and $\left.\delta^{15} N\right)$ isotope values for human and animal bone collagen from Early Neolithic Osłonki 1 in north-central Poland (c. 4600-4100 cal BC). A new series of AMS radiocarbon determinations show that, of individuals interred at the same time, those with copper artefacts exhibit significantly higher $\delta^{13} C$ values than those without. Our results suggest a link between high status goods and intra-community differences in diet and/or preferential access to the agropastoral landscape.

Keywords: North European Plain, Neolithic, Brześć Kujawski Group, dietary isotopes, social status 


\section{Introduction}

The emergence of asymmetries in social and economic standing in prehistoric communities has long been a central focus of archaeological research (e.g. Price \& Feinman 1995; Mulder Borgerhoff et al. 2009). The primary approach to the study of past inequality relies on objects included in burials that are thought to reflect differences in the deceased's status, indicated by differential access to non-local materials or by grave goods that exhibit superior craftsmanship. With the spread of agriculture, social differentiation and hereditary inequality eventually became correlated with political and ideological complexity (Price 1995). Bronze Age and Iron Age burials containing lavish concentrations of durable and 'costly' goods may be read as signalling marked status differences in later prehistoric Europe (Parker Pearson 1999). During the European Neolithic, however, variation in grave goods is not easily attributable to status differences. The presence and quantity of exotic materials may not directly reflect an individual's social standing during life, but may have been motivated by performances or displays by surviving kin, aimed at mitigating against death and the processes surrounding it (Robb 2013). Ornaments may also simply reflect personal taste or style, even if they are made from non-local materials or are finely crafted.

The human skeleton, however, provides an independent archive to apprehend the links between social standing in life and treatment in death. Osteological markers of activity and episodic stress offer one approach (e.g. Robb et al. 2001), while stable carbon and nitrogen isotopes $\left(\delta^{13} \mathrm{C}\right.$ and $\left.\delta^{15} \mathrm{~N}\right)$, which yield insights into aspects of an individual's diet, offer another. The intersection between variability in grave goods and in stable isotope values permits more robust investigation of socioeconomic inequality in early farming societies. Mulder Borgerhoff and colleagues (2009), for example, have found that long-term inequality depends on the extent to which the most important forms of wealth are transmitted within families and across generations. Of particular interest is the finding that in pastoral and agricultural economies, cattle, land and other material wealth tend to be transmitted directly by simple transfer, within a framework of social conventions of inheritance. The rise and expansion of multi-household settlements and the presence of easily transferable material wealth (e.g. permanent fields and cattle), provided fertile ground for the emergence of socioeconomic inequality (Mulder Borgerhoff et al. 2009).

Here, we explore the link between diet and socioeconomic inequality, reflected by copper grave goods in burials from Osłonki 1, a multi-generation Neolithic settlement of the fifth millennium $\mathrm{BC}$ in north-central Poland. We present $\delta^{13} \mathrm{C}$ and $\delta^{15} \mathrm{~N}$ data from bone collagen for 30 human and 128 faunal samples, and new AMS radiocarbon dates for 17 
individuals. Osłonki provides a robust archive against which we can test hypotheses concerning the relationship between social complexity and differential access to food, as well as between mortuary treatment and individual life experiences.

\section{Investigating status in life and death}

Stable isotope analyses to investigate links between diet and social status in prehistoric Europe have had varying success. In later prehistory and the medieval period, high-status individuals or those identified as 'warriors', have been shown to have higher $\delta^{15} \mathrm{~N}$ values, plausibly interpreted as representing preferential access to animal protein (Le Huray \& Schuktowski 2005; Knipper et al. 2015; see also Privat et al. 2002). Few studies, however, have identified such links for the Neolithic. Despite disparities in grave goods, no corresponding isotopic differences were identified, for example, at either the Early Neolithic Linearbandkeramik (LBK) site of Herxheim, or the Middle Neolithic site of Trebur, both in southern Germany (Dürrwächter et al. 2006). Of course, this need not indicate that no dietary differences existed, only that they involved foods that were not isotopically distinct.

Individuals in Middle Neolithic chamber graves in the Languedoc-Roussillon region of southern France had significantly higher $\delta^{15} \mathrm{~N}$ values than those interred in simple pit graves at neighbouring sites, suggesting higher meat consumption for the former. This was interpreted as a partitioning of the landscape between herders and farmers rather than intracommunity inequality (Le Bras-Goude et al. 2013). A similar subdivision of the landscape on an even finer spatial scale has been suggested for the Late Neolithic/Early Chalcolithic communities in the Ebro valley of north-central Spain who interred their dead in caves versus megalithic monuments (Fernández-Crespo \& Schulting 2017).

\section{Osłonki and the Brześć Kujawski Group of the North European Plain}

During the fifth millennium BC, the Polish lowlands of the North European Plain witnessed renewed expansion and consolidation of sedentary communities practising a mixed farming economy. The Brześć Kujawski Group (BKG) was a regional variant of the Lengyel culture, a major post-LBK culture of east-central Europe (Bogucki \& Grygiel 2015). Sites previously abandoned by LBK groups were reoccupied, new locations chosen, and persistent occupations with multiple large structures emerged, suggesting the consolidation of a new phase of agricultural communities in the lowlands (Czerniak et al. 2016; Bogucki 2019).

Osłonki 1 is a large settlement located in the Kuyavia region of north-central Poland, approximately $10 \mathrm{~km}$ west of the town of Brześć Kujawski on the Kuyavian plain (Figure 1). 
Extensive excavations undertaken between 1989 and 1994 have revealed over 30 longhouses and more than 80 graves containing 92 human skeletons, along with a defensive ditch and palisade (Grygiel 2008). An initial series of 30 conventional radiocarbon assays on charcoal provided a date range for the BKG occupation of c. 4600-4100 BC (Grygiel 2008; Bogucki \& Grygiel 2015). Like most Neolithic dryland open sites in temperate Europe, Osłonki presents a palimpsest of features whose chronology is difficult to disentangle. Based on these legacy "conventional" radiocarbon dates and typological analysis of ceramics, Grygiel (2008) defined three phases - 'early,' 'classic' and 'late'—for BKG sites in the Brześć KujawskiOsłonki region. At Osłonki, early materials are confined to the southern edge of the excavated area, while classic and late features are found across the site. Construction of the fortification ditch separates the classic from the late phases. Although these phases are assumed to represent a continuous sequence, our new AMS dates from the Osłonki burials raise the possibility of one or more temporal breaks, even though burials occurred throughout the occupation of Osłonki, across the entire excavated area (Figure 2). Often, they are found adjacent to houses, leading to their incorporation into a settlement model of household clusters. In several cases, the graves form "microcemeteries" of two to five adjacent burials.

The mortuary behaviour of the BKG and other Lengyel groups is highly structured and ritualised, with attention paid to skeletal positioning and the inclusion of many types of grave goods. These include copper ornaments (the earliest in northern Europe), hip belts made of shell beads, bone armlets, and occasional antler axes and bone daggers. BKG communities interacted over long distances and developed complex social relationships, illustrated by the presence of exotic materials and objects in graves (Grygiel 2008; Bogucki \& Grygiel 2015).

Palaeobotanical evidence from Osłonki and nearby BKG sites indicates that a suite of domestic species, dominated by emmer wheat (Triticum dicoccum), with smaller quantities of einkorn (Triticum monococcum), 'new type' glume wheat (Triticum sp.), and peas (Pisum sativum) (Bieniek 2007; Mueller-Bieniek et al. 2016) were exploited. Domestic cattle and sheep/goat remains dominate the BKG faunal assemblage at Osłonki, representing $\sim 34$ and $\sim 35$ per cent of the assemblage respectively, while pig bones comprise $\sim 25$ per cent of the identified specimens (Bogucki 2008). Wild fauna, such as red and roe deer (Cervus elaphus and Capreolus capreolus) are present, although not abundant, alongside small quantities of wild pig (Sus scrofa), wild horse (Equus ferus), beaver (Castor fiber) and aurochs (Bos primigenius). Terrestrial and aquatic birds were also exploited, along with fish (including perch [Perca fluviatilis], pike [Esox lucius] and cyprinids) and pond turtle (Emys 
orbicularis). The faunal assemblage suggests a focus on meat production, supplemented by dairying (Bogucki 2008), with the wild fauna and flora providing additional dietary variety and perhaps helping to offset periodic resource shortfalls.

Of the 92 individuals buried at Osłonki, 22 (approximately 24 per cent) were accompanied by copper objects. These range from a worn fragment of copper in Burial 34a to a diadem composed of some 50 rectangular copper strips, along with 200 beads and five pendants, in Burial 13 (Grygiel 2008; see Table S1 in the online supplementary material (OSM)). Copper artefacts accompanied both male and female adolescents and adults, as well as two young children ( $<5$ years). Twelve burials with copper ornaments (Figure 3 ) were among the 30 analysed here. Although no definitive provenance data are yet available, the nearest known copper sources exploited during the fifth millennium BC are located several hundred kilometres away in the eastern Alps and the Carpathians. Similar copper forms occur in contemporaneous sites in Silesia and Bohemia (Grygiel 2008).

Copper and shell beads are the two most common artefact categories in the Osłonki burials. Shell beads are by far the most abundant, with several individuals having hip belts made of 600 to 700 beads. The range of other grave goods include amber objects, calcite beads, perforated animal tooth pendants, bone ornaments, bone and flint tools, T-shaped antler axes, stone axes and ceramics (Grygiel 2008). While there are no clear associations between burials with copper and any other specific artefact category, graves with copper tend to contain a higher number of other artefact types overall: $1.45 \mathrm{vs} .0 .61$ in graves lacking copper, a difference that is statistically significant (Mann-Whitney test, $p<0.001$ ). This applies to the site as a whole, as well as to the subset of graves analysed isotopically. Thus, graves with copper are more likely to contain other objects, whether this reflects 'wealth' or some other form of social or symbolic capital.

\section{Stable isotopes and diet}

Stable isotope analysis for palaeodietary reconstruction is based on the principle that ${ }^{13} \mathrm{C}$ and ${ }^{15} \mathrm{~N}$ in foods is incorporated into the consumer's tissues (Lee-Thorp 2008; Makarewicz \& Sealy 2015). Briefly, $\delta^{13} \mathrm{C}$ values vary between plants following $\mathrm{C}_{3}$ and $\mathrm{C}_{4}$ photosynthetic pathways, and between terrestrial and marine systems. At Osłonki, the isotopic ecology is entirely $\mathrm{C}_{3}$-based, with access to marine foods unlikely, given that the site lies approximately $200 \mathrm{~km}$ inland from the Baltic coast. Freshwater systems are more variable, and need to be addressed case by case (Dufour et al. 1999). As for $\delta^{15} \mathrm{~N}$, this refers primarily to trophic level, increasing by approximately 3-5\% from herbivore to carnivore (Hedges \& Reynard 2007). 
Confounding factors include aridity (not an issue in north-central Europe) and anthropogenic inputs, most notably manuring. The latter significantly elevates soil ${ }^{15} \mathrm{~N}$, and hence the $\delta^{15} \mathrm{~N}$ values of plants growing on these soils (Bogaard et al. 2013). When interpreting stable isotope results, it is important to recognise that measurements on bone collagen are biased towards dietary protein in the case of $\delta^{13} \mathrm{C}$, meaning that plant foods will typically be underrepresented as they contain less protein (Ambrose \& Norr 1993). As nitrogen is found predominantly in protein, $\delta^{15} \mathrm{~N}$ informs only on that macronutrient , again emphasising animal foods. Measurements made on adult bone collagen provide an average of foods eaten over the last decade or so of life.

\section{Diet in life}

The faunal isotopic results are consistent with a temperate $\mathrm{C}_{3}$ ecosystem (Table 1; Figure 4; OSM 1). The combined domestic (cattle and sheep/goat) and wild herbivore (red and roe deer) $\delta^{13} \mathrm{C}$ values show little variation, together averaging $-20.5 \pm 0.5 \%$ o $(\mathrm{n}=93)$. Values for domestic pigs $(-20.9 \pm 0.7 \%)$ and wild boar $(-21.0 \pm 0.4 \%$ ) are slightly lower (Mann-Whitney U-test comparing herbivores and domestic pig/wild boar; $Z=3.27 ; p=0.001$ ), possibly reflecting more foraging in closed canopy forest conditions by pigs (cf. Bonafini et al. 2013). The $\delta^{15} \mathrm{~N}$ values of domestic pigs $(7.3 \pm 1.0 \% ; \mathrm{n}=20)$ are significantly elevated above both wild boar $(5.5 \pm 0.8 \% ; \mathrm{n}=6)$ and herbivores $(5.7 \pm 1.0 \% ; \mathrm{n}=93)$ (ANOVA with Bonferroni post-hoc corrections, $p<0.001$ ), suggesting that, in addition to foraging, they were fed village scraps, including animal products. While no freshwater fish remains were available for sampling, five pond turtle bones average $-24.4 \pm 0.9 \%$ and $6.8 \pm 0.5 \%$ for $\delta^{13} \mathrm{C}$ and $\delta^{15} \mathrm{~N}$, respectively, confirming that the local freshwater system is ${ }^{13} \mathrm{C}$-depleted relative to the terrestrial system.

Carbon and nitrogen isotope data for carbonised cereals at Osłonki 1 have been recently published $(\mathrm{n}=9)$, providing $\delta^{13} \mathrm{C}$ values of $-20.2 \pm 0.3 \%$ and $\delta^{15} \mathrm{~N}$ values of $4.2 \pm 0.6 \%$, with the latter suggesting a moderate level of manuring (Mueller-Bieniek et al. 2019: tab. 3). Considered against these faunal and flora results, human $\delta^{13} \mathrm{C}$ and $\delta^{15} \mathrm{~N}$ values $\left(\delta^{13} \mathrm{C}=-20.2 \pm 0.3 \% ; \delta^{15} \mathrm{~N}=8.5 \pm 0.5 \%\right.$ ) at Osłonki 1 are entirely consistent with a reliance on terrestrial plant and animal protein resources. No significant differences are observed between the sexes for either $\delta^{13} \mathrm{C}(p=0.525)$ or $\delta^{15} \mathrm{~N}(p=0.897)$, nor are any differences apparent within the adolescent and adult age categories (no infants or children were included in the study). The herbivore average of $5.7 \pm 1.0 \%$ is $2.8 \%$ below the human average. This is 
less than a trophic-level enrichment, and is thus consistent with the consumption of both plants and animal products (e.g. meat and/or milk).

\section{Linking status in life and in death}

The limited variability in human $\delta^{13} \mathrm{C}$ and $\delta^{15} \mathrm{~N}$ values and the fact that they are typical for Neolithic farmers across much of central and northern Europe (Hedges et al. 2013; Schulting 2018) initially suggest that there is little of interest beyond documenting known regional trends. Osłonki 1, however, provides the opportunity to compare individuals interred with copper grave goods to those without. As noted above, this distinction appears to have been observed by the community, albeit subtly, in that individuals buried with copper objects were more likely to also have a greater variety of other non-perishable grave offerings. Individuals interred with copper grave goods have, on average, more positive $\delta^{13} \mathrm{C}$ values than those without such goods $(-19.9 \pm 0.3 \%$ vs. $-20.4 \pm 0.3 \% ; t=4.36 ; p=0.001)$ (Figure 5; OSM 1). Cohen's $d$ measures the difference between the two means expressed in pooled standard deviations; by convention, values above 0.8 are characterised as large (Cohen 1988). For $\delta^{13} \mathrm{C}$ at Osłonki, Cohen's $d=1.56$. The difference observed here is therefore meaningful, as well as statistically significant. There is no corresponding difference in $\delta^{15} \mathrm{~N}$ values $(8.6 \pm 0.4 \%$ vs . $8.5 \pm 0.5 \% ; t=1.09 ; p=0.282)$.

\section{Dating the Osłonki burials}

The calibrated dates for 17 burials at Osłonki (OSM 3) range from 4445-4261 to 4227-3972 cal BC (using OxCal v.4.2.2 with IntCal13 calibration curve at 95.4\% probability; Bronk Ramsey 2019; Reimer et al. 2013). There is no evidence for freshwater reservoir effects based on $\delta^{15} \mathrm{~N}$ values. This is consistent with the paucity of aquatic resources (cf. Juras et al. 2017). In the absence of stratigraphic or other independent dating evidence, the burials are treated as belonging to a single phase of activity for Bayesian analysis (Bronk Ramsey 2009a). The onset of burial is modelled in the range 4385-4260 BC, ending at 4220-3990 BC (at $95.4 \%$ confidence). Importantly for the present discussion, radiocarbon dates demonstrate that individuals with and without copper grave offerings are contemporaneous (Figure 6; OSM 3).

The modelled dates on human bone are also largely consistent with previously available determinations made on charcoal (Grygiel 2008; Bogucki \& Grygiel 2015), modelled using a 'charcoal outlier model', which assumes a variable degree of in-built age due to the old wood effect (Bronk Ramsey 2009b). When unconstrained by the burials, the 
start of occupation at Osłonki is modelled as 4515-4280 BC, ending at 4235-3945 BC (Figure 6). When constrained by the burials, the modelled start date shifts only slightly to 4415-4275 BC. The close agreement of the two series further indicates that any significant freshwater reservoir offsets affecting the human dates are unlikely. The human results are comparable to dates (mainly on faunal bone) at Racot 18, another Late Lengyel BKG site (Figure 1), modelled as starting at 4385-4285 BC, ending at 3965-3915 BC (Czerniak et al. 2016: 9). Three determinations on humans from the settlement and burial site of Krusza Zamkowa (Figure 1) also date to c. 4300-4000 cal BC (Juras et al. 2017).

\section{Discussion}

The most notable outcome of our study is that individuals interred with copper grave goods at Osłonki have, on average, significantly higher $\delta^{13} \mathrm{C}$ values compared to their counterparts without copper artefacts. The question remains as to how this outcome can be interpreted in terms of diet. That a corresponding difference is not observed in $\delta^{15} \mathrm{~N}$ makes it challenging to identify the underlying food sources. A diet richer in animal protein, for example, should result in higher $\delta^{15} \mathrm{~N}$ values, although this can be complicated by ${ }^{15} \mathrm{~N}$-enrichment in plants due to manuring of fields (Fraser et al. 2011; Bogaard et al. 2013), for which there seems to be evidence at Osłonki (Mueller-Bieniek et al. 2019).

Given their importance in the faunal assemblage at Osłonki (especially when considering meat-weight), cattle probably dominated the animal protein component of the diet, providing both meat and milk (Salque et al. 2013). Dairy products are depleted in ${ }^{13} \mathrm{C}$, but have $\delta^{15} \mathrm{~N}$ values similar to those for meat, and could therefore lead to the observed differences, i.e., individuals interred without copper grave goods could have consumed more dairy products. However, despite abundant evidence of cheese-making by LBK communities in Kuyavia during the late sixth millennium BC (Salque et al. 2013), there is currently little direct evidence of dairying at Osłonki a millennium later, other than two fragments of strainers amongst the nearly 36000 pottery sherds (Grygiel 2008: figs. $428 \& 668$ ).

Comparing the isotopic values of cattle remains from different contexts at Osłonki constitutes another approach. A significant difference is seen in the average $\delta^{13} \mathrm{C}$ values of samples taken from four pits, each providing at least four specimens (ranging from four to 26) (ANOVA, $F=2.93, p=0.03$ ); Bonferroni post-hoc comparisons indicate that the difference is driven by pit 137 (see Grygiel 2008 for context information). Assuming discrete depositional events, this suggests that some cattle were reared on isotopically-distinct pastures, raising the possibility of long-term, intra-community differences in cattle 
management. Confirmation of this will require additional analyses, combined with radiocarbon dating to exclude a diachronic trend. The site's relatively short occupation period and the contexts of the pits suggests that changes over time are not the cause of the pattern observed here.

If we accept that the evidence from pit 137 indicates differential pasturing of animals, then it is possible to suggest that different members or sections of the community may have had long-term access to plants and animals from isotopically-distinct areas of land (cf. Bogaard et al. 2011). Larger fields and pastures, because they are exposed to higher light levels, would be expected to be slightly enriched in ${ }^{13} \mathrm{C}$ compared to smaller, more shaded fields (cf. Bonafini et al. 2013) — as would the animals grazing on them. Such fields and pastures would also be more productive and desirable in what was still a largely wooded landscape (Bogucki et al. 2012). Perhaps founding members of the community had privileged access to these fields, and, by extension, to the exchange networks that brought precious copper ornaments this far north. Although speculative, this is a plausible scenario, given the abundant ethnographic evidence for the importance ascribed to the 'first settlers' in a region and/or to a community's founders (Freeman 1970; Strathern 1971; Kopytoff 1987). Such 'first settlers' were perhaps the people identified in preliminary analysis of ancient DNA from Osłonki and Krusza Zamkowa as comprising primarily individuals with immigrant farmer ancestry, ultimately of Near Eastern origin, but with some individuals retaining mitochondrial markers of hunter-gatherer ancestry (Lorkiewicz et al. 2015; Juras et al. 2017). Furthermore, there are indications that distinctions were made in Early Neolithic Central Europe, with individuals buried with stone adzes-important markers of identity and status-in LBK cemeteries being more likely to be of local origins (Bentley et al. 2002, 2012).

The main point here is that a significant difference exists in $\delta^{13} \mathrm{C}$ values between individuals interred with and without copper artefacts. As stable isotope measurements on bone collagen reflect foods consumed over the last decade or more of adult life, this difference implies a long-term difference in diet, whether as a result of consuming different foods, or of consuming essentially the same foods, but obtained from isotopically distinct parts of the surrounding landscape. This helps reinforce the image projected by the funerary treatment accorded to these individuals.

The multi-generation differences in human diet and unequal access to exotic grave goods observed at Osłonki-possibly underpinned by differential access to high-quality cattle pasture-are consistent with the interpretive framework of socioeconomic inequality advanced by Mulder Borgerhoff and colleagues (2009) and with the emerging view of 
Lengyel society during the fifth millennium BC. Grave goods and mortuary rites at Lengyel settlements, such as Alsónyék-Bátaszék, Zengővárkony and Aszód-Papi földek in Hungary (Siklósi 2007; Zalai-Gaál 2010; Osztás et al. 2012) and Svodín in Slovakia (Demján 2015), have been interpreted as indicating social differentiation. The isotopic evidence from Osłonki provides support for this scenario.

During the fifth millennium BC, Lengyel culture communities flourished from Croatia to the North European Plain. The Lengyel culture sensu lato has been characterised as an 'interaction sphere' within which materials circulated and practices were widely shared (Czerniak \& Pyzel 2016), the BKG being a prominent regional participant. Whether the Lengyel culture, in its many forms, meets the formal attributes of an interaction sphere (as defined by Caldwell 1964) is a worthwhile topic of discussion, to which the Osłonki data can contribute. In such an interaction sphere, local elites seek to acquire exogenous materials as markers of status, which are often displayed within a ritual context, while local subsistence and craft production practices function independently (Hayden \& Schulting 1997).

The association between copper ornaments and diet observed in the Osłonki burials speaks for the engagement of the BKG with a larger Lengyel interaction sphere. The copper found in mortuary contexts provides evidence for the supra-local circulation of goods used to advance the interests of a privileged segment of society, which would have signalled values and behaviour connecting prominent inhabitants of Osłonki with other parts of the Lengyel world and beyond. Rather than simply viewing them as commodities, we can consider the copper artefacts at Osłonki as markers of participation in a trans-regional interaction sphere by individuals with differential access to dietary resources. Perhaps this entailed preferential access to better fields and pastures by lineages claiming descent from community founders.

Finally, it is worth commenting on the evidence for episodes of interpersonal violence at Osłonki, including skeletal trauma and the construction of a palisade and ditch (Grygiel 2008; Lorkiewicz 2012). The eventual abandonment of Osłonki was not an isolated occurrence, as occupation at other BKG sites also appears to have ceased at the end of the fifth millennium (Czerniak et al. 2016). This raises the possibility that a regional collapse occurred prior to the arrival of another tradition, the Funnel Beaker culture (Bogucki 1996; Grygiel 2016). Moreover, the exchange networks that introduced copper ornaments to northern Europe broke down, and did not re-appear for a millennium (Osipowicz et al. 2018). Thus, as well as linking diet with status, Osłonki provides an example of the precarious nature of socioeconomic inequality. 


\section{Conclusions}

Osłonki provides some of the earliest direct evidence in Europe for a relationship between diet in life and treatment in death. Copper artefacts were included as grave goods for some 200 years at this location, suggesting that the dichotomy of copper- $v s$. non-coppercontaining burials reflects a real difference in the long-term diets of members of the community. That the system appears quite short-lived highlights that early attempts at developing hierarchical structures were not always successful in the long term. On a broader level, our study shows that isotopic analyses are not merely a sophisticated analytical tool but capable of giving insights into the socioeconomic structure that underpins a community's existence.

\section{Acknowledgments}

The authors would like to thank Peter Ditchfield (Research Laboratory for Archaeology and the History of Art, University of Oxford) for assistance with mass spectrometry. The Wetland Archaeology \& Environments Research Centre at the University of Hull provided radiocarbon funding.

\section{Supplementary material}

To view supplementary material for this article, please visit XXXX

\section{References}

Ambrose, S.H. \& L. NoRR. 1993. Experimental evidence for the relationship of the carbon isotope ratios of whole diet and dietary protein to those of bone collagen and carbonate, in J.B. Lambert \& G. Grupe (ed.) Prehistoric human bone: archaeology at the molecular level: 1-37. New York: Springer. https://doi.org/10.1007/978-3-662-02894-0_1

Bentley, R.A., T.D. Price, J. Lüning, D. Gronenborn, J. Wahl \& P.D. Fullagar. 2002. Prehistoric migration in Europe: strontium isotope analysis of Early Neolithic skeletons. Current Anthropology 43: 799-804. https://doi.org/10.1086/344373

BENTLEY, R.A. et al. 2012. Community differentiation and kinship among Europe's first farmers. Proceedings of the National Academy of Sciences of the USA 109: 9326-30. https://doi.org/10.1073/pnas.1113710109

BIENIEK, A. 2007. Neolithic plant husbandry in the Kujawy region of central Poland, in S. Colledge \& J. Conolly (ed.) The origins and spread of domestic plants in South-west Asia and Europe: 315-26. Walnut Creek (CA): Left Coast. 
BogaArd, A., R. Krause \& H.-C. Strien. 2011. Towards a social geography of cultivation and plant use in an early farming community: Vaihingen an der Enz, south-west Germany. Antiquity 85: 395-416. https://doi.org/10.1017/S0003598X00067831

BogAARD, A. et al. 2013. Crop manuring and intensive land management by Europe's first farmers. Proceedings of the National Academy of Sciences of the USA 110: 12589-94. https://doi.org/10.1073/pnas.1305918110 BoguCKI, P. 1996. Sustainable and unsustainable adaptations by early farming communities of northern Poland. Journal of Anthropological Archaeology 15: 289-311. https://doi.org/10.1006/jaar.1996.0011 - 2008. Animal exploitation by the Brześć Kujawski Group in the Brześć Kujawski and Osłonki region, in R. Grygiel (ed.) Neolit i Początki Epoki Brązu w Rejonie Brześcia Kujawskiego and Osłonek, volume II: 1581-704. Łódź: Fundacja Badań Archeologicznych imienia Profesora Konrada Jażdżewskiego, Muzeum Archeologiczne i Etnograficzne. - 2019. On the periphery and at a crossroads: a Neolithic creole society on the Lower Vistula in the fifth millennium BC, in R. Gleser \& D. Hofmann (ed.) Contacts, boundaries \& innovation in the fifth millennium: exploring developed Neolithic societies in Central Europe and beyond: 45-57. Leiden: Sidestone.

Bogucki, P. \& R. Grygiel. 2015. Pioneer farmers at Brześć Kujawski, Poland, in G. Barker \& C. Goucher (ed.) The Cambridge world history, volume 2: a world with agriculture, 12 000 BCE-500 CE: 589-611. Cambridge: Cambridge University Press. https://doi.org/10.1017/CBO9780511978807.024 Bogucki, P., D. NAlePKA, R. GRYgiel \& B. NowaczyK. 2012. Multiproxy environmental archaeology of Neolithic settlements at Osłonki, Poland, 5500-4000 BC. Environmental Archaeology 17: 45-65. https://doi.org/10.1179/1461410312Z.0000000004

Bonafini, M., M. Pellegrini, P. Ditchfield \& A.M. Pollard. 2013. Investigation of the 'canopy effect' in the isotope ecology of temperate woodlands. Journal of Archaeological Science 40: 3926-35. https://doi.org/10.1016/j.jas.2013.03.028

BRONK RAMSEY, C. 2009a. Bayesian analysis of radiocarbon dates. Radiocarbon 51: 337-60. https://doi.org/10.1017/S0033822200033865

-2009b. Dealing with outliers and offsets in radiocarbon dating. Radiocarbon 51: 1023-45. https://doi.org/10.1017/S0033822200034093 - 2019. OxCal 4.3. https://c14.arch.ox.ac.uk/oxcal/OxCal.html. CALDWELl, J.R. 1964. Interaction spheres in prehistory, in J.R. Caldwell \& R.L. Hall (ed.) Hopewellian studies: 133-43. Springfield: Illinois State Museum. 
COHEN, J. 1988. Statistical power analysis for the behavioral sciences. London: Routledge. CZERniaK, L. \& J. PyzEL. 2016. Being at home in the Early Chalcolithic: the longhouse phenomenon in the Brześć Kujawski Culture in the Polish Lowlands. Open Archaeology 2: 97-114. https://doi.org/10.1515/opar-2016-0007

Czerniak, L., A. Marciniak, C. Bronk Ramsey, E. Dunbar, T. Goslar, A. Barclay, A. BAYliss \& A. WhitTle. 2016. House time: Neolithic settlement development at Racot during the $5^{\text {th }}$ millennium cal BC in the Polish lowlands. Journal of Field Archaeology 41: 618-40. https://doi.org/10.1080/00934690.2016.1215723

DEMJÁN, P. 2015. Evidence of social structure of a Neolithic community in Svodín, southwest Slovakia. Anthropologie 53(3): 363-73.

Dufour, E., H. Bocherens \& A. MARIOTTI. 1999. Palaeodietary implications of isotopic variability in Eurasian lacustrine fish. Journal of Archaeological Science 26: 617-27. https://doi.org/10.1006/jasc.1998.0379

Dürrwächter, C., O.E. Craig, M.J. Collins, J. Burger \& K.W. Alt. 2006. Beyond the grave: variability in Neolithic diets in southern Germany? Journal of Archaeological Science 33: 39-48. https://doi.org/10.1016/j.jas.2005.06.009

FERNÁNDEZ-CRESPO, T. \& R.J. SCHULTING. 2017. Living different lives: early social differentiation identified through linking mortuary and isotopic variability in Late Neolithic/ Early Chalcolithic north-central Spain. PloS ONE 12: e0177881.

https://doi.org/10.1371/journal.pone.0177881

FRASER, R.A. et al. 2011. Manuring and stable nitrogen isotope ratios in cereals and pulses: towards a new archaeobotanical approach to the inference of land use and dietary practices. Journal of Archaeological Science 38: 2790-804. https://doi.org/10.1016/j.jas.2011.06.024 FreEMAN, D. 1970. Report on the Iban. London: Athlone.

GrygIEL, R. 2008. Neolit i początki epoki brązu w rejonie Brześcia Kujawskiego i Osłonek. Tom II, Środkowy neolit: Grupa Brzesko-Kujawska kultury Lendzielskiej. Łódź: Fundacja Badań Archeologicznych imienia Profesora Konrada Jażdżewskiego, Muzeum Archeologiczne i Etnograficzne.

- 2016. Neolit i początki epoki brązu w rejonie Brześcia Kujawskiego i Osłonek. Tom III, Środkowy i póżny neolit: Kultura Pucharów Lejkowatych. Łódź: Fundacja Badań Archeologicznych imienia Profesora Konrada Jażdżewskiego, Muzeum Archeologiczne i Etnograficzne.

HAyden, B. \& R.J. Schulting. 1997. The Plateau Interaction Sphere and late prehistoric cultural complexity. American Antiquity 62: 51-85. https://doi.org/10.2307/282379 
Hedges, R.E.M. et al. 2013. The supra-regional perspective, in P. Bickle \& A. Whittle (ed.) The first farmers of Central Europe: diversity in LBK Lifeways: 343-84. Oxford: Oxbow. HEDGES, R.E.M. \& L.M. REYNARD. 2007. Nitrogen isotopes and the trophic level of humans in archaeology. Journal of Archaeological Science 34: 1240-51.

https://doi.org/10.1016/j.jas.2006.10.015

JURAS, A. et al. 2017. Investigating kinship of Neolithic post-LBK human remains from Krusza Zamkowa, Poland using ancient DNA. Forensic Science International: Genetics 26: 30-39. https://doi.org/10.1016/j.fsigen.2016.10.008

KNIPPER, C. et al. 2015. Superior in life - superior in death: dietary distinction of central European prehistoric and medieval elites. Current Anthropology 56: 579-89. https://doi.org/10.1086/682083 KOPYTOFF, I. 1987. The importance of being first, in I. Kopytoff (ed.) The African frontier: the reproduction of traditional African societies: 121-22. Bloomington: Indiana University Press.

Le Bras-Goude, G., E. Herrscher \& J. Vaquer. 2013. Funeral practices and foodstuff behaviour: what does eat meat mean? Stable isotope analysis of Middle Neolithic populations in the Languedoc region (France). Journal of Anthropological Archaeology 32: 280-87. https://doi.org/10.1016/j.jaa.2012.01.005

LE HuRAY, J.D. \& H. SchutKowSKI. 2005. Diet and social status during the La Tène period in Bohemia: carbon and nitrogen stable isotope analysis of bone collagen from Kutná HoraKarlov and Radovesice. Journal of Anthropological Archaeology 24: 135-47.

https://doi.org/10.1016/j.jaa.2004.09.002

LEe-Thorp, J.A. 2008. On isotopes and old bones. Archaeometry 50: 925-50.

https://doi.org/10.1111/j.1475-4754.2008.00441.x

LORKIEWICZ, W. 2012. Skeletal trauma and violence among the early farmers of the North European Plain: evidence from Neolithic settlements of the Lengyel Culture in Kuyavia, north-central Poland, in R.J. Schulting \& L. Fibiger (ed.) Sticks, stones and broken bones: Neolithic violence in a European perspective: 51-76. Oxford: Oxford University Press. https://doi.org/10.1093/acprof:osobl/9780199573066.003.0004

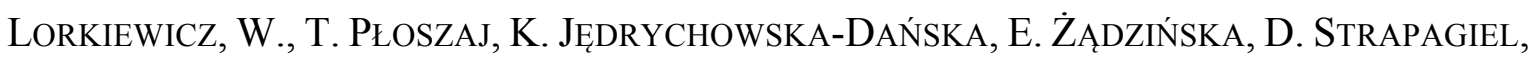
E. Haduch, A. SzCZEPANEK, R. GRygiel \& H.W. WitAs. 2015. Between the Baltic and Danubian worlds: the genetic affinities of a middle Neolithic population from central Poland. PloS ONE 10: e0118316. https://doi.org/10.1371/journal.pone.0118316 MAKAREWICZ, C.A. \& J. SEALY. 2015. Dietary reconstruction, mobility, and the analysis of 
ancient skeletal tissues: Expanding the prospects of stable isotope research in archaeology. Journal of Archaeological Science 56: 146-58. https://doi.org/10.1016/j.jas.2015.02.035 Mueller-Bieniek, A., P. Kittel, B. Muzolf, K. Cywa \& P. Muzolf. 2016. Plant macroremains from an early Neolithic site in eastern Kuyavia, central Poland. Acta Palaeobotanica 56: 79-89. https://doi.org/10.1515/acpa-2016-0006

Mueller-Bieniek, A., M. Nowak, A. Styring, M. Lityńska-Zając, M.D. Hoyo, A. SojkA, B. PaszKo, K. Tunia \& A. BogaArd. 2019. Spatial and temporal patterns in Neolithic and Bronze Age agriculture in Poland based on the stable carbon and nitrogen isotopic composition of cereal grains. Journal of Archaeological Science: Reports 101993. https://doi.org/10.1016/j.jasrep.2019.101993

Mulder BorgerhofF, M. et al. 2009. Intergenerational wealth transmission and the dynamics of inequality in small-scale societies. Science 326: 682-88.

https://doi.org/10.1126/science.1178336

Osipowicz, G., J. Kuriga, D. MaKowiecki, M. Bosiak \& R. Grygiel. 2018. Evidence for widespread occurrence of copper in Late Neolithic Poland? A deposit of Funnel Beaker Culture bone products at site 2 in Osłonki (Kuyavia, central Poland). Quaternary International 472: 60-74. https://doi.org/10.1016/j.quaint.2017.10.036

OszTÁs, A., I. ZALAI-GAÁL \& E. EsZTER BÁNFFY. 2012. Alsónyék-Bátaszék: a new chapter in the research of Lengyel culture. Documenta Praehistorica 39: 377-96.

https://doi.org/10.4312/dp.39.27

Parker Pearson, M. 1999. The archaeology of death and burial. Stroud: Sutton.

PRICE, T.D. 1995. Social inequality at the origins of agriculture, in T.D. Price \& G.M.

Feinman (ed.) Foundations of social inequality: 129-51. New York: Plenum.

https://doi.org/10.1007/978-1-4899-1289-3_5

Price, T.D. \& G.M. FeINMAN (ed.). 1995. Foundations of social inequality. New York:

Plenum. https://doi.org/10.1007/978-1-4899-1289-3

Privat, K.L., T.C. O'CONNELL \& M.P. RichaRds. 2002. Stable isotope analysis of human and faunal remains from the Anglo-Saxon cemetery at Berinsfield, Oxfordshire: dietary and social implications. Journal of Archaeological Science 29: 779-90.

https://doi.org/10.1006/jasc.2001.0785

Reimer, P.J., E. Bard, A. BAyliss, J.W. Beck, P.G. Blackwell, C. Bronk RAMSEy, C.E. Buck, H. Cheng, R.L. Edwards, M. Friedrich, P.M. Grootes, T.P. Guilderson, H. Haflidason, I. Hajdas, C. Hatté, T.J. Heaton, D.L. Hoffmann, A.G. Hogg, K.A. Hughen, K.F. Kaiser, P. Kromer, S.W. Manning, M. Niu, R.W. Reimer, D.A. Richards, E.M. SCOtT, J.R. Southon, R.A. Staff, C.S.M. Turney, \& J. VAN DER Plicht. 2013. 
IntCal13 and Marine13 Radiocarbon Age Calibration Curves 0-50,000 Years cal BP. Radiocarbon 55(4): 1869-87.

RoBB, J.E. 2013. Creating death: an archaeology of dying, in S. Tarlow \& L. Nilsson Stutz (ed.) The Oxford handbook of the archaeology of death and dying: 441-57. Oxford: University Press.

RobB, J.E., R. Bigazzi, L. LAZzarini, C. SCARsini \& F. Sonego. 2001. Social "status" and biological "status": a comparison of grave goods and skeletal indicators from Pontecagnano. American Journal of Physical Anthropology 115: 213-22. https://doi.org/10.1002/ajpa.1076 Salque, M., P.I. Bogucki, J. Pyzel, I. Sobkowiak-Tabaka, R. Grygiel, M. Szmyt \& R.P. EVERSHED. 2013. Earliest evidence for cheese making in the sixth millennium BC in northern Europe. Nature 493: 522-25. https://doi.org/10.1038/nature11698

SchUlting, R.J. 2018. Dietary shifts at the Mesolithic-Neolithic transition in Europe: an overview of the stable isotope data, in J. Lee-Thorp \& M.A. Katzenberg (ed.) The Oxford handbook of the archaeology of diet. Oxford: Oxford University Press.

https://doi.org/10.1093/oxfordhb/9780199694013.013.35

SIKLÓSI, Z. 2007. Age and gender differences in Late Neolithic mortuary practice: a case study from Eastern Hungary, in J.K. Kozłowski \& P. Raczky (ed.) The Lengyel, Polgár and related cultures in the Middle/Late Neolithic in Central Europe: 185-98. Kraków: Polish Academy of Arts and Sciences.

STRATHERn, A. 1971. The rope of Moka. Cambridge: Cambridge University Press. https://doi.org/10.1017/CBO9780511558160

ZALAI-GAÁL, I. 2010. Die soziale Differenzierung im Spätneolithikum Südtransdanubiens. Budapest: Varia Archaeologica Hungarica 24. 
Table 1. Summary of $\delta^{13} \mathrm{C}$ and $\delta^{15} \mathrm{~N}$ values from human and fauna bone collagen.

\begin{tabular}{|l|c|c|c|c|c|}
\hline Species & & $\delta^{13} C$ & $\delta^{13} C$ & $\delta^{15} N$ & $\delta^{15} N$ \\
\hline Human females & 14 & -20.1 & 0.4 & 8.5 & 0.6 \\
\hline Human males & 16 & -20.3 & 0.3 & 8.5 & 0.4 \\
\hline Cattle & 45 & -20.6 & 0.4 & 5.9 & 0.7 \\
\hline Sheep/Goat & 30 & -20.1 & 0.4 & 5.7 & 0.8 \\
\hline Pig & 20 & -20.8 & 0.7 & 7.3 & 1.0 \\
\hline Wild boar & 6 & -21.0 & 0.3 & 5.5 & 0.7 \\
\hline Roe Deer & 7 & -20.7 & 0.8 & 5.0 & 0.7 \\
\hline Red Deer & 10 & -20.8 & 0.7 & 4.7 & 1.4 \\
\hline Horse & 1 & -22.3 & - & 3.9 & - \\
\hline Dog & 2 & -18.9 & 0.9 & 8.2 & 0.7 \\
\hline Beaver & 1 & -20.5 & - & 8.5 & - \\
\hline Turtle & 5 & -24.4 & 0.9 & 6.8 & 0.5 \\
\hline Aurochs & 1 & -20.4 & - & 7.8 & - \\
\hline
\end{tabular}

\section{Figure captions}

Figure 1. Map of the lower Vistula drainage showing areas of Brześć Kujawski Group settlement and locations of sites mentioned in the text.

Figure 2. Simplified plan of the settlement at Osłonki, showing trapeziform longhouses and distribution of burials. Burials outlined with black squares were isotopically analysed for this project. Burials shaded in red contained copper artefacts (after Grygiel 2008: fig. 404).

Figure 3. Burial 54 at Ostonki: left) arrangement of skeleton with copper plaques visible near hand; right) copper plaques and beads, shell beads and other ornaments (after Grygiel 2008: fig. 813).

Figure 4. $\delta^{13} C$ and $\delta^{15} N$ graph for human and faunal bone collagen.

Figure 5. $\delta^{13} C$ and $\delta^{15} N$ boxplots.

Figure 6. Bayesian model for dated human burials at Osłonki. 